\title{
Sulfur and oxygen isotopic geochemistry of sulfate in the black ore deposits of Japan
}

\author{
Hitoshi SAKaI ${ }^{1}$, SUSUMU OSAKI ${ }^{2}$ \\ and MASANOBU TSUKAGISHI ${ }^{3}$ \\ Institute for Thermal Spring Research, \\ Okayama University, Misasa, 682-02 ${ }^{1}$, \\ Department of Earth Sciences, Nagoya \\ University, Nagoya, $464^{2}$, and \\ Department of Geology, Kanazawa University, \\ Kanazawa, $920^{3}$, Japan
}

(Received February 14, 1970)

\begin{abstract}
The sulfur isotopic values of barite, gypsum and anhydrite from the typical strata-bound submarine ore deposits (black ore deposits) of Miocene age in Japan have a narrow range of +21 to $24 \%$ with respect to the meteoritic sulfur. However, the oxygen isotopic values (in SMOW) vary from +5 to $+19 \%$ and have a general tendency to increase in the order : barite $<$ anhydrite $\approx$ alabaster $<$ secondary gypsum (satin spar and selenite). The sulfate minerals from the late Paleozoic cupriferrous iron sulfide ore deposits of the Yanahara and Besshi mines are similar in the sulfur isotopic values $(+11$ to $+15 \%$ ) to inferred Permian sea water sulfate, whereas the oxygen isotopic values have a wide range of variation.

The observed sulfur isotopic pattern is most likely due to a submarine hydrothermal system in which sulfate of marine origin (connate or actual sea water) predominated over other sources of sulfur. The variable oxygen isotopic data of sulfate are explained by the oxygen isotopic exchange between sulfate and water during depositional and post-depositional processes. The sulfur and oxygen isotopic ratios of "hot sulfate" in the Wairakei and the Red Sea geothermal brines are consistent with this idea.

The sulfates in secondary gypsum ores in the Noto mine are enriched in both ${ }^{34} \mathrm{~S}$ and ${ }^{18} \mathrm{O}$, suggesting that the alteration of the primary ores in this mine may have taken place under the influence of sulfate-reducing bacteria.
\end{abstract}

\section{INTRODUCTION}

The $\delta^{34} \mathrm{~S}$ values of sulfate in many hydrothermal deposits are similar to those of evaporite deposits of the same geologic age. Sulfates in some of the presently active geothermal systems such as at Wairakei, New Zealand (STEINER and RAFTER, 1966; RAFTer and Mizutani, 1967) and the Red Sea (HARTMAnN and NiElsen, 1966) are isotopically similar to sea water sulfate. These facts seem to support the view that sulfate in certain hydrothermal ore deposits originates from contemporaneous sea 
water sulfate, as was originally discussed by BuSCHENDORF et al. (1963) for the sulfate at Meggen/Lenne, Germany. Isotopically, a question arises whether these hydrothermal sulfates were directly inherited from ancient sea water sulfate or they experienced reactions during mineralization, resulting in sulfur isotopic exchange between sulfate and sulfide.

Differences of +17 to $+20 \%$ (in terms of the $\delta^{34} \mathrm{~S}$ values of sulfate and sulfide) occur between coexisting sulfate and sulfide minerals in many hydrothermal deposits. These fractionations correspond to "isotopic temperatures" of 300 to $400^{\circ} \mathrm{C}$ according to the isotopic temperature scales by SAKAI (1968). Alternatively, however, the similar fractionations can also be obtained as the result of simple mixing of sea water sulfate of $\delta^{34} \mathrm{~S}=$ about $20 \%$ and sulfide close to zero permil. The sulfide sulfur may be of magmatic origin or bacterially derived from the sea water sulfate, itself. OANA and IsHIKAWA (1966) and NAKAI (1967) demonstrated experimentally that, under favorable conditions, sulfate and sulfide can isotopically equilibrate with each other in hydrothermal solution. However, a more definitive criterion than the sulfur isotopic fractionation factor is required to determine the isotopic relationship between sulfate and sulfide as well as the origin of sulfate.

Recent developments by RAFTER (1967) in oxygen isotopic analysis of sulfate stimulated us to study the problem from a new angle, that is, oxygen isotopic exchange between sulfate and water. The Japanese black ore deposits are submarine strata-bound sulfide-sulfate ore deposits containing abundant barite, gypsum and anhydrite. A number of these sulfate samples from several black ore deposits were analyzed for their sulfur and oxygen isotopic ratios in an effort to detect any evidences of isotopic exchange. A few sulfate samples from sulfate-poor strata-bound sulfide deposits of possibly Permian age were also analyzed.

\section{Geological Settings of the Ore Deposits}

Black ore deposits are found widely in the "Green Tuff" region, where Miocene marine clastic sediments occur with numerous pyroclastics and lava flows of submarine volcanic activities. The geology of the "Green Tuff" region is outlined by the Geological Survey of Japan (1960).

The black ore deposits of the present study may be divided into two types : typical black ore deposits and "black ore type" gypsum deposits. Shakanai (SAKAZAKI et al., 1965) and Kosaka (Hashimoto et al., 1962) mines, Akita-Pref. (Fig. 1), belong to the first type. Fig. 2 is a schematic vertical cross section of the Shakanai deposit. The sulfide ore consists of successive layers from the top to the bottom, of "Kuroko" (black ore), "Oko" (yellow ore), and "Keiko" (siliceous ore) generally underlain by abundant "gypsum ore". "Kuroko" is compact aggregate of fine grained sphalerite, galena, and barite with minor pyrite, chalcopyrite, and sulfosalts. "Oko" is massive 


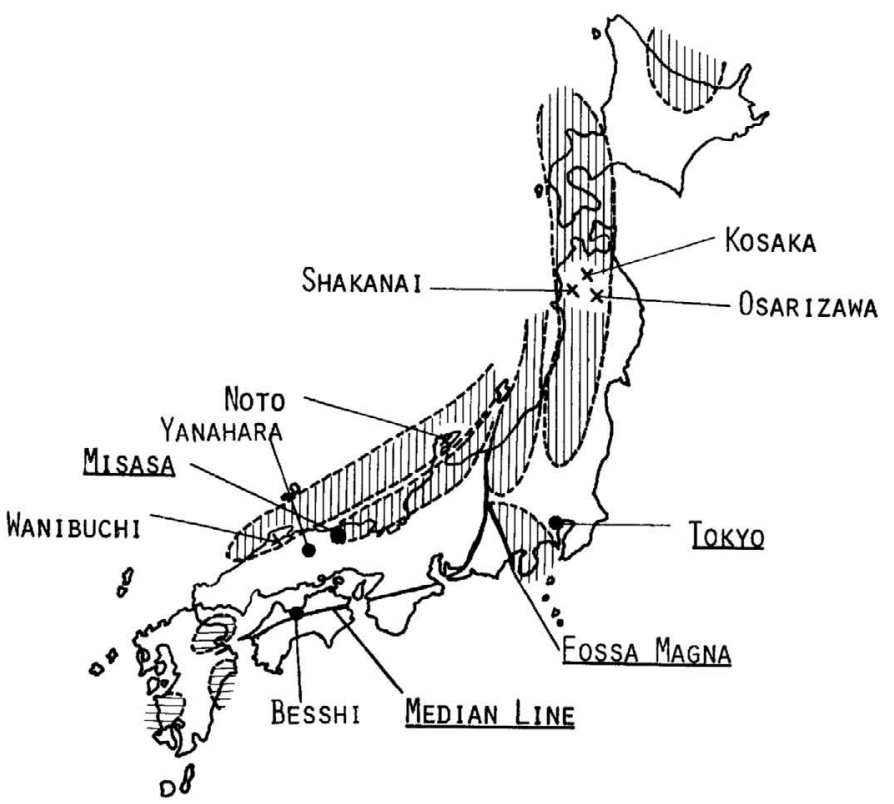

Fig.1. A map showing the Green Tuff region (shaded area) and the localities of the mines studied.

NIIII Green Tuff Provinces (Lower Middle to Upper Miocene)

Green Tuff Provinces (Upper Middle to Upper Miocene)

(After MATSUMOTO, T. unpublished)

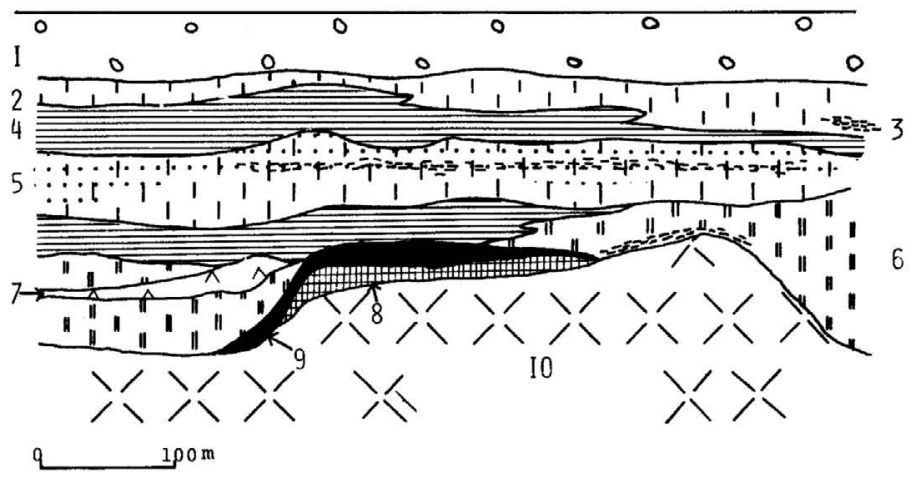

Fig.2. Schematic cross section of a typical black ore deposit in the Shakanai mine, Akita-Pref. (after SAKAZAKI et al., 1965).

(1) gravel bed, (2) Sainogami tuff, (3) weakly mineralized zone,

(4) mud stone, (5) silicified tuff, (6) Shakanai tuff, (7) dolerite,

(8) gypsum ore, (9) sulfide ores("Kuroko", "Oko" and "Keiko"),

(10) rhyolite. 
pyritic ore with chalcopyrite, and "Keiko" is pyrite-quartz ore with varying amounts of chalcopyrite. The amount of barite in "Kuroko" varies within an ore body and within a district.

The Noto (Sugrura, 1956) and Wanibuchi (IwaO, 1956) mines in the southwestern part of the "Green Tuff" region represent the second type. Sulfide minerals occur sporadically as massive balls embedded in gypsum. The gypsum ore of this type is closely associated with oily black shales; the typical black ores are usually found in rhyolite and rhyolitic tuffs.

In both types of deposits, gypsum occurs in three forms: alabaster (fine grained and massive), satin spar (in veins and networks) and selenite (coarse crystalline, massive, or in veins). Anhydrite and alabaster often form the main part of a gypsum ore body and are considered to be primary. Most satin spar and selenite veins apparently are secondary products of early formed anhydrite and alabaster. The amount of gypsum varies throughout a deposit, but might exceed the sulfides in abundance by an order of magnitude.

For the purpose of isotopic comparison, some sulfate minerals from the Tanosawa vein of the Osarizawa mine, Akita-Pref., and from the cupriferrous iron sulfide deposits in Permian rocks at the Yanahara mine, Okayama-Pref., and a selenite from the Besshi mine, Ehime-Pref., also were analyzed (see Fig.1). The Osarizawa mine is in the same metallogenic province as the black ore deposits (TATSUMI, 1965). The ore deposits are typical fissure-filling, chalcopyrite-chlorite-quartz veins. The Tanosawa vein studied in this research is rich in galena, sphalerite, and barite. The ore deposits of the Besshi mine are mantos of cupriferrous iron sulfides in the Sanbagawa crystalline schist; the age of ore deposition is supposedly late Paleozoic (WATANABE, 1957). At the Yanahara mine (Oshima, 1958), massive to lenticular cupriferrous iron sulfide ores are embedded in less metamorphosed Paleozoic rocks. Because both of these deposits have few sulfate minerals, the number of available samples is limited. The sulfur isotopic geochemistry of the Yanahara mine has been described by Yамамото et al. (1968).

\section{EXPERIMENTAL}

About $200 \mathrm{mg}$ of powdered gypsum or anhydrite was dissolved into $100 \mathrm{ml}$ of $1 \mathrm{~N}$ $\mathrm{HCl}$ solution, and any insoluble materials were filtered off. The filtrate was diluted to $500 \mathrm{ml}$ by distilled water, and barium sulfate was precipitated as usual. Barite was purified as far as possible by hand picking, heavy liquid and/or an isodynamic separator. When necessary, crude barite samples were finely powdered and subjected to the successive treatments by $6 \mathrm{~N} \mathrm{HCl}, \mathrm{HF}-\mathrm{HCl}$-, and $\mathrm{HNO}_{3}-\mathrm{Br}_{2}$-mix tures to remove acid soluble sulfides, silicates, and acid insoluble sulfides, respectively. As shown by HoERING and KENNEDY (1957), the rate of oxygen isotopic exchange between sulfate ion and water during the conversion of gypsum into barium sulfate is too slow to affect the isotopic results (though it may be rapid enough in a geological time scale as will be 
discussed below). Several aliquots of a powdered gypsum were converted into barium sulfate by using two kinds of water of which $\delta^{18} \mathrm{O}$ values are +0.0 and $-7.8 \%$, respectively. The $\delta^{18} \mathrm{O}$ values of the two groups of barium sulfate did not show any differences implying that no isotopic exchange between water and sulfate occurred as predicted above.

Barium sulfate, precipitated or natural, was converted into carbon dioxide for oxygen isotopic measurements by the modified procedures of RAFTER (1967) or converted into sulfur dioxide for the sulfur isotopic ratio measurements according to SAKAI and Yамамото (1966). The isotopic ratio measurements were carried out by a McKinney-type mass spectrometer. The results are expressed in the familiar meteoritic sulfur $\left(\delta^{34} \mathrm{~S}\right)$ and SMOW $\left(\delta^{18} \mathrm{O}\right)$ scales. The reproducibility of the measurements is $\pm 0.2 \%$ for sulfur and $\pm 0.3 \%$ for most of oxygen analyses.

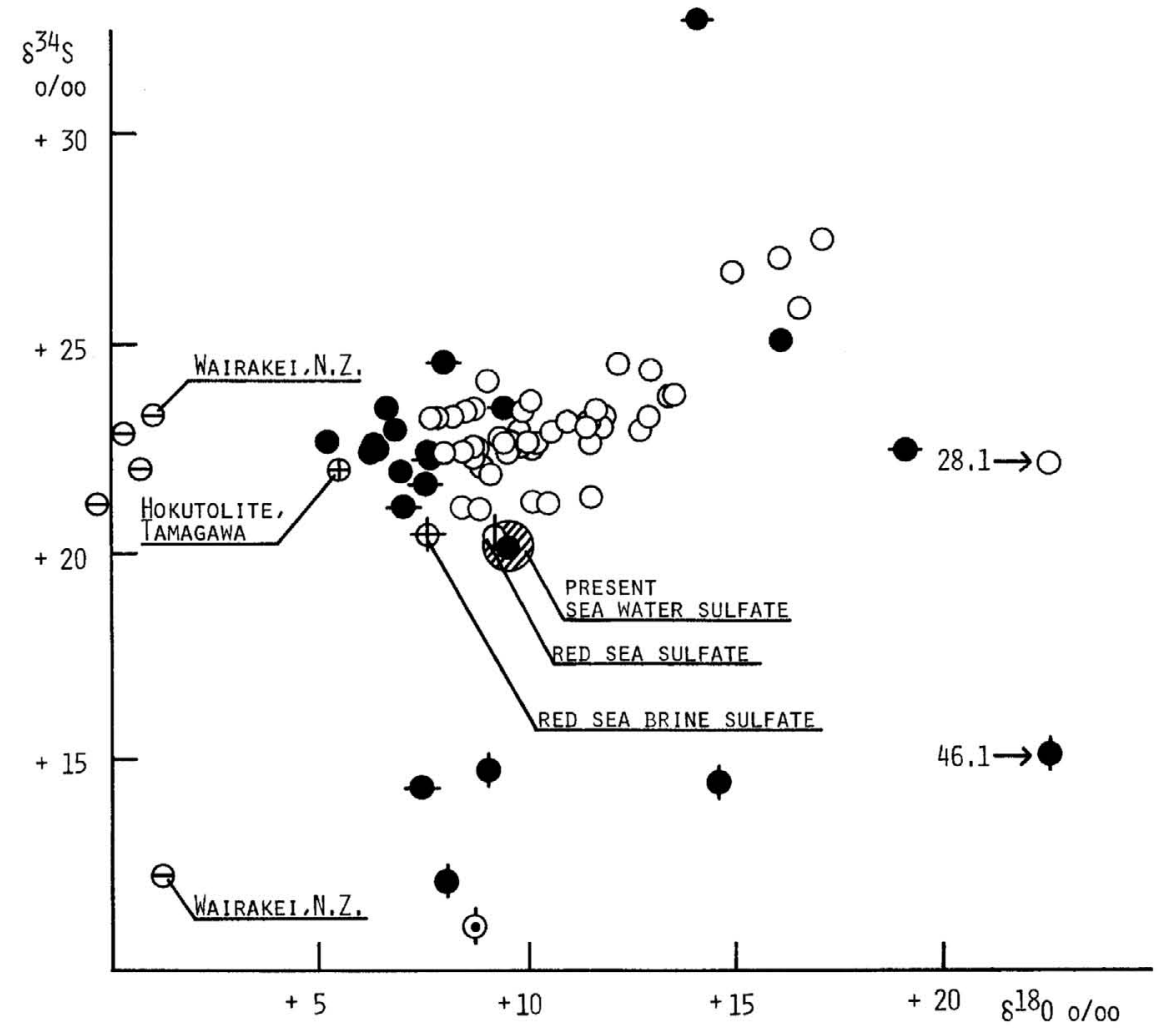

Fig.3. Relation between the sulfur and oxygen isotope ratios of barite and gypsum in the black ore deposits and the cupriferrous iron sulfide deposits. - : barite, and 0 : gypsum (including anhydrite) in the black ore deposits

- : barite from the Tanosawa vein in the Osarizawa mine

$\phi$ : barite from the Yanahara mine $\phi$ : selenite from the Besshi mine 


\section{RESULTS}

In Fig. $3,{ }^{34} \mathrm{~S}$ values of barite, gypsum and anhydrite from the black ore deposits and other mines are plotted against their $\delta^{18} \mathrm{O}$ values. The data on sulfates in the present sea water (THODE et al., 1961; LONGINELLI and CRAIG, 1967), in the geothermal brines at Wairakei, New Zealand (RAFTER and Mizutani, 1967), and in the Red Sea (Hartmann and Nielsen, 1966; Craig, 1966) also are included.

The sulfates from the Shakanai and Kosaka mines and most of the sulfates from the Wanibuchi mine have a narrow range of $\delta^{34} \mathrm{~S}$ values (from +21 to $+24 \% 0$ ) and a large oxygen isotopic variation. The $\delta^{18} \mathrm{O}$ values of anhydrite in these mines generally are similar to those of alabaster closely associated with it; however, the lowest $\delta^{18} \mathrm{O}$ values in an ore body are often in anhydrite. Barite of the typical black ore deposits is definitely depleted in $\delta^{18} \mathrm{O}$ compared to the gypsum ores, but no significant difference exists in their sulfur isotopic ratios. The sulfates from the Wairakei geothermal brines are located on the extreme left side of this group except for one having $\delta^{34} \mathrm{~S}=+12 \%$. The sulfates from the Yanahara and Besshi mines have distinctly different $\delta^{34} \mathrm{~S}$ values of +11 to $+15 \%$, and their $\delta^{18} \mathrm{O}$ values have a large range of variation. Fig. 4 is a separate plot of barite and gypsum from the Shakanai mine; secondary gypsums appear to be enriched in ${ }^{18} \mathrm{O}$ compared to anhydrite and alabaster.

The Noto gypsum samples differ from other Miocene sulfates in that the $\delta^{34} \mathrm{~S}$ values increase proportionally with $\delta^{18} \mathrm{O}$ (see Fig.5). The satin spars also are enriched in both heavy isotopes compared to alabaster and anhydrite. Alabaster which replaces a shell in the black shale of the Noto mine and is apparently secondary has the highest

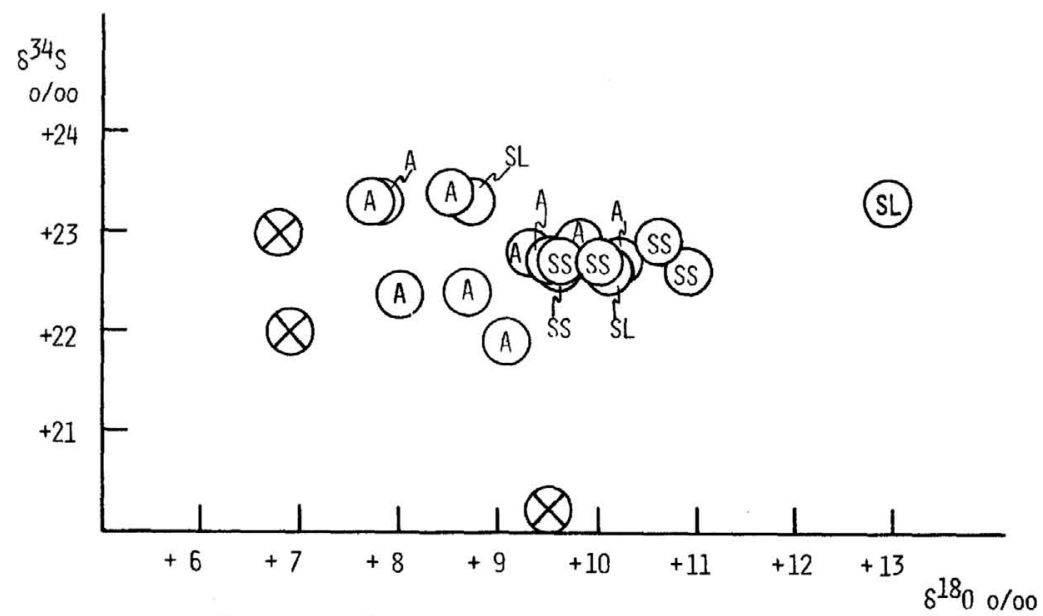

Fig.4. $\quad \delta^{34} \mathrm{~S}$ and $\delta^{18} \mathrm{O}$ values of the sulfates from the Shakanai mine, Akita-Pref. $Q$ : barite; (A) : anhydrite and alabaster;

(SS) : satin spar; (SL) : selenite 


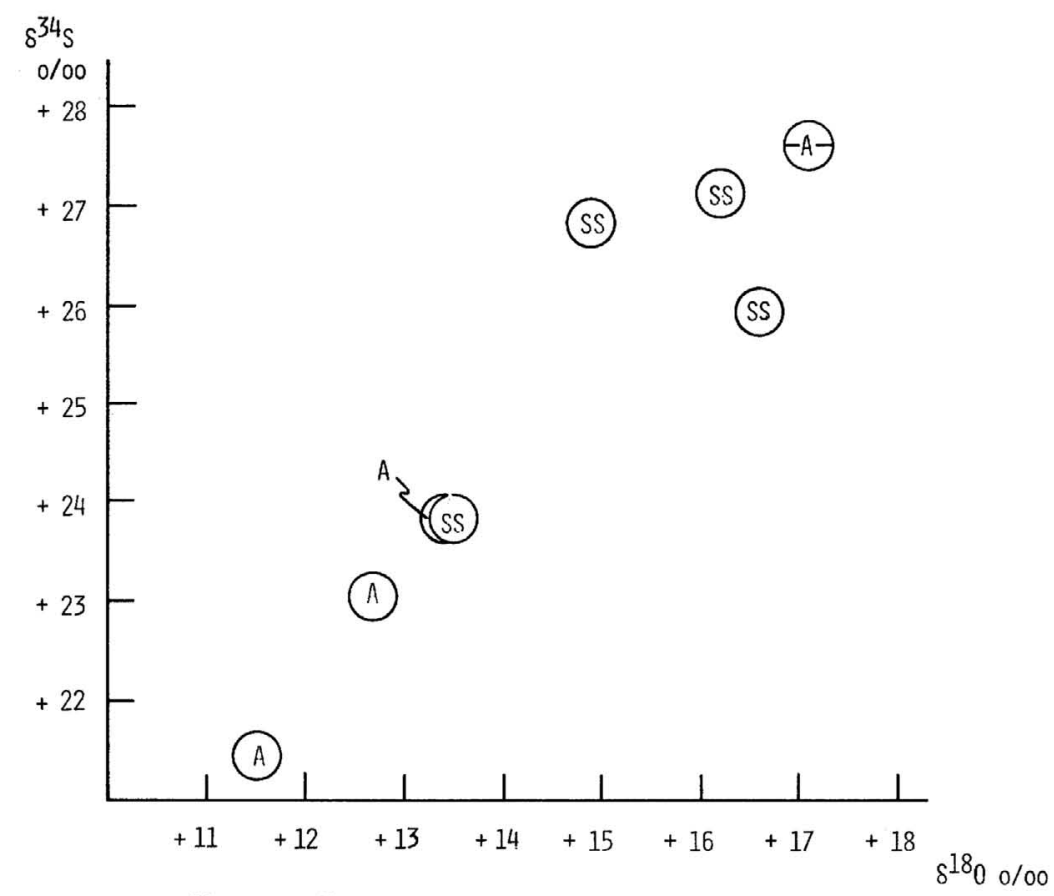

Fig.5. $\delta^{34} \mathrm{~S}$ and $\delta^{18} \mathrm{O}$ values of the gypsum ores from the Noto mine. (A): alabaster; (SS) : satin spar; (A): alabaster replacing a shell

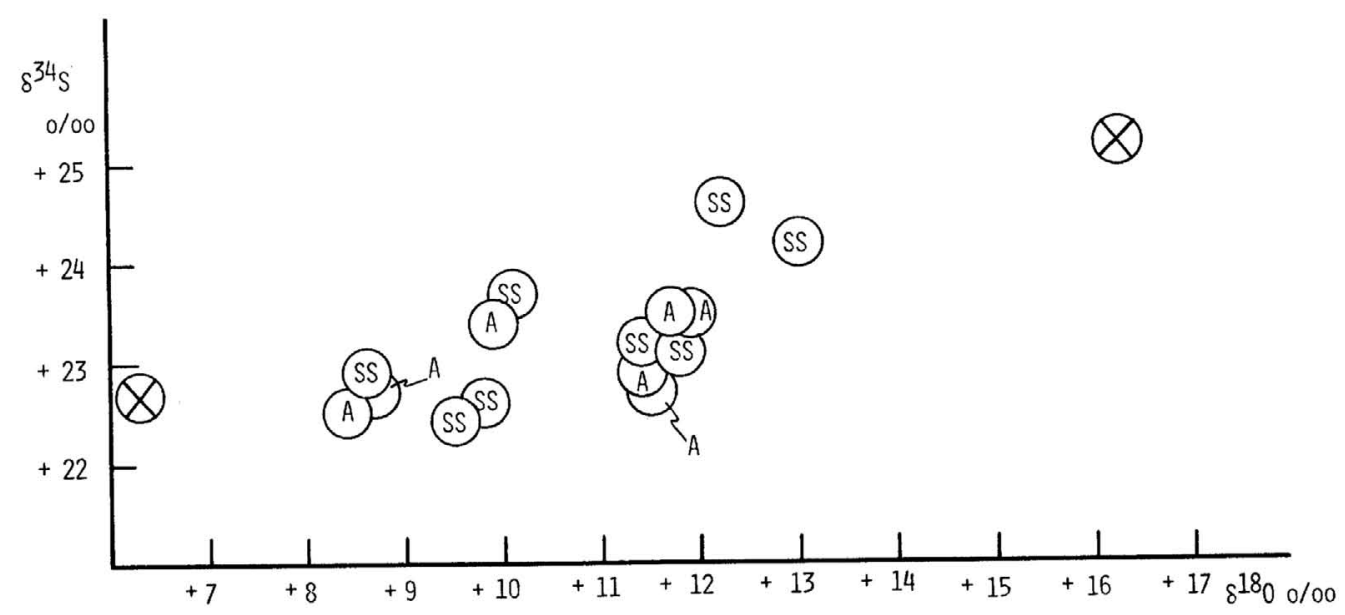

Fig.6. $\delta^{34} \mathrm{~S}$ and $\delta^{18} \mathrm{O}$ values of the gypsum ores from the Wanibuchi mine.

$\bigotimes$ : barite; SS satin spar; (A) anhydrite and alabaster 
$\delta^{34} \mathrm{~S}$ and $\delta^{18} \mathrm{O}$ values. A similar, but much less significant trend is also seen in some of the Wanibuchi samples (Fig.6).

The $\delta^{34} \mathrm{~S}$ values of pyrite in these deposits also have narrow ranges, +4 to $7 \%$ from the black ore deposits (SAKaI and Yамамото, unpublished) and +1 to $+3 \%$ from the Yanahara and Besshi mines (YамAmoto et al., 1968; Yamamoto, unpublished).

\section{DISCUSSION}

The narrow range of sulfur isotopic results suggests that the sulfur isotopic ratios of sulfate in the ore-forming solutions were similar to those of the Miocene sea water sulfates and remained almost unchanged throughout all depositional stages of the black ore deposits in the Shakanai and Kosaka mines and during the main stages in the Wanibuchi mine. Furthermore, the sulfates in the geothermal areas shown in Table 1 have $\delta^{34} \mathrm{~S}$ values very close to those of sea water sulfate.

Table $1 \delta^{34} \mathrm{~S}$ and ${ }^{18} \mathrm{O}$ values of sulfate and water in some geothermal systems

\begin{tabular}{|c|c|c|c|c|c|c|c|}
\hline \multirow[b]{2}{*}{ Locality } & \multirow[b]{2}{*}{ Temp. ${ }_{\mathrm{C}}^{\mathrm{ob}}$} & \multicolumn{2}{|c|}{$\delta^{34} \mathrm{~S}$} & \multicolumn{2}{|c|}{$\delta^{18} \mathrm{O}$} & \multirow[b]{2}{*}{$\begin{array}{l}\text { Isotopic* } \\
\text { temp. }{ }^{\circ} \mathrm{C}\end{array}$} & \multirow[b]{2}{*}{ Reference } \\
\hline & & $\mathrm{SO}_{4}^{2-}$ & Sulfide & $\mathrm{SO}_{4}^{2-}$ & $\mathrm{H}_{2} \mathrm{O}$ & & \\
\hline \multicolumn{8}{|l|}{ a. The Red Sea } \\
\hline sea water & 22.2 & +20.3 & & +9.14 & +1.92 & & $\mathrm{~A}\left(\delta^{34} S\right)$ \\
\hline brine & 40 & +20.3 & +4.3 & +7.51 & +1.21 & $250(0)$ & $\mathrm{B}\left(\delta^{18} \mathrm{O}\right)$ \\
\hline b. Wairakei brine & 300 & $\begin{array}{r}+21.2 \\
\sim+23.3\end{array}$ & $+3.0^{* *}$ & -0.4 & -5.3 & $\begin{array}{l}290(\mathrm{O}) \\
330(\mathrm{~S})\end{array}$ & $\begin{array}{l}\mathrm{C}\left(\delta^{34} \mathrm{~S}\right) \\
\mathrm{D}\left(\delta^{18} \mathrm{O}, \delta^{34} \mathrm{~S}\right)\end{array}$ \\
\hline c. Tamagawa Hot Springs & 98 & +22.0 & $-2.0 * *$ & $+5.4 * * *$ & & & $\mathrm{E}$ \\
\hline
\end{tabular}

References: A=HARTMANN and NIELSEN (1966); B=CRAIG (1966); C=STEINER and RAFTER (1966); D=RAFTER and MIZUTANI (1967); E=SAKAI (1957)

* The oxygen isotopic temperatures (denoted by $\mathrm{O}$ ) are estimated based on the experimentally determined temperature scale of the bisulphate-water system (MIZUTANI and RAFTER, 1969a). The sulfur isotopic temperature (denoted by S) is based on the theoretical temperature scale between sulfate ion and hydrogen sulfide (SAKAI, 1968).

** Hydrogen sulfide

*** Hokutolite

The $\delta^{34} \mathrm{~S}$ values of the late Paleozoic Yanahara and Besshi deposits in Fig. 3 could be explained by recalling that the $\delta^{34} \mathrm{~S}$ of the Permian sea water sulfates have the same range (between +11 to $+15 \%$, NIELSEN, 1965; NIELSEN and RICKE, 1964). These facts definitely support the view originally expressed by BusCHENDORF et al. (1963) for the sulfates at Meggen/Lenne that sulfates in certain hydrothermal submarine or volcanic deposits are ultimately derived from sea water sulfates (from connate or actual sea water). 
However, the large oxygen isotopic variations suggest that the sulfates were not simply inherited from sea water sulfates, but have been adapted isotopically to the new chemical environment of each hydrothermal system. According to HoERING and KENNEDY (1957), the rate of the oxygen isotopic exchange reaction between sulfate ion and water is proportional to the concentration of hydrogen ion $\left(\left[\mathrm{H}^{+}\right]\right)$and bisulfate ion $\left(\left[\mathrm{HSO}_{4}^{-}\right]\right)$in solution and rapidly increases with increasing temperature, that is: $\quad R=A\left[\mathrm{H}^{+}\right]\left[\mathrm{HSO}_{4}^{-}\right] \mathrm{g} \cdot$ atom $/ 1 \cdot \mathrm{sec}$,

where $R$ is the reaction rate and $A$ a constant at a given temperature. For example, in a hydrothermal solution of $\mathrm{pH}=1, T=100^{\circ} \mathrm{C}$, and sulfate concentration of 10 millimole, which actually exists in the Tamagawa Hot Springs, Akita-Pref. (see Table 1), the half-time of the exchange reaction should be a few years, as extrapolated from the experimental results by these authors. Therefore, under favorable conditions, sulfate ion in hydrothermal solution can equilibrate isotopically with water during transportation and deposition. MizUTANI and RAFTER (1969a) have shown this for the sulfates in the geothermal brines at Wairakei, New Zealand, having the temperature of $300^{\circ} \mathrm{C}$.

OANA and IsHIKAWA (1966) showed experimentally that the exchange rate of sulfur isotopes between sulfate and native sulfur is rather rapid when they are formed by disproportionation of sulfurous acid in hydrothermal solution. NAKAI (1967) even demonstrated that sulfate ion and pyrite synthesized in a hydrothermal bomb at temperatures from 200 to $300^{\circ} \mathrm{C}$ reached isotopic exchange equilibrium with each other within a few hours in the presence of excess native sulfur. Furthermore, some of the sulfate-sulfide pairs in the geothermal brines at Wairakei, New Zealand (RAFTER and MizUTANI, 1967) and at Matsukawa, Japan (NAKAI, 1968) exhibit isotopic fractionation factors which closely correspond to the observed temperatures. These works combined with the foregoing discussion on the oxygen isotopic values support the view that the sulfate in natural hydrothermal solution may isotopically equilibrate with sulfide during mineralization.

However, even when sulfur isotopic exchange occurs between sulfate and sulfide in hydrothermal solution, the original $\delta^{34} S$ values of the sea water sulfates could remain almost unchanged if the amount of the sulfate was vastly greater than the amount of sulfide sulfur. In submarine hydrothermal systems, the $\delta^{34} \mathrm{~S}$ values would be mostly controlled by the isotopic composition of the sea water sulfates. Conversely, because the amount of water in natural hydrothermal systems greatly exceeds the amount of dissolved sulfate, the $\delta^{18} \mathrm{O}$ value of the sulfate at any given temperature would largely be controlled by the isotopic composition of the water. The extremely low ${ }^{18} \mathrm{O}$ contents of the Wairakei sulfates in Table 1 are, for instance, apparently due to the low ${ }^{18} \mathrm{O}$ contents of the brines with which the sulfates are equilibrated (MIzUTANI and RAFTER, 1969a). On the other hand, the isotopic composition of the brine water in the Red Sea is essentially the same as the Red Sea water (CRAIG, 1966) and, therefore, the sulfate in the brine is heavier in ${ }^{18} \mathrm{O}$ than the Wairakei sulfates. The oxygen isotopic 
temperature, $250^{\circ} \mathrm{C}$, obtained for the submarine geothermal system in the Red Sea, may be compatible with the current idea that the brines are the results of the leaching of evaporites by the Red Sea water circulating downwards to a geothermal reservoir (Miller et al., 1966; Craig, 1966).

The foregoing discussion suggests that the sulfates in the black ore deposits were precipitated from the submarine hydrothermal systems where sulfate of oceanic origin (probably of Miocene age) was the predominant sulfur species. The $\delta^{18} \mathrm{O}$ values and/or temperature of the ore fluid changed with time and locality, as reflected in the large oxygen isotopic variation in the sulfates. Hydrogen and oxygen isotopic studies of the fluid inclusion in sulfide and sulfate minerals and of the water of crystallization of gypsum are in progress in this laboratory for a further understanding of the ore forming and post-depositional processes.

Sulfate-reducing bacteria could also play an important role in controlling both the sulfur and oxygen isotopic ratios of sulfate in a shallow basin, where influx of sea water is limited. When they reduce sulfate, the bacteria prefer ${ }^{32} \mathrm{~S}^{16} \mathrm{O}_{4}^{2-}$ rather than ${ }^{32} \mathrm{~S}^{16} \mathrm{O}_{3}{ }^{18} \mathrm{O}^{2-}$ (LlOYd, 1968; Mizutani and RAFTER, 1969b) and ${ }^{34} \mathrm{SO}_{4}^{2-}$ (HARrison and THODE, 1958), resulting in the significant enrichment of the heavy isotopes of sulfur and oxygen in the remaining sulfate in solution. If the residual sulfates (remaining in solution) after considerable bacterial reduction were involved in the diagenesis of the gypsum ores, the gypsum would exhibit variably heavy sulfur and oxygen isotopic values. Perhaps this occurred in the Noto and Wanibuchi mines. This hypothesis is supported by the geologic evidence that the Miocene seas of these areas were rather shallow and had many islands (KASENO, 1963).

SANGSTER (1968) showed that a parallel variation exists between the $\delta^{34} S$ values of strata-bound sulfide deposits and contemporaneous sea water sulfates throughout geologic time. In the sulfide deposits associated with volcanic rocks, the apparent fractionation factor between sulfide and contemporaneous sea water sulfate is almost invariably $17.5 \%$, whereas in the sulfide deposits associated with sedimentary rocks, it is more variable, averaging $11.7 \%$. He concluded that the sulfur of these stratabound deposits was derived from contemporaneous sea water sulfate by action of sulfate reducing bacteria. However, SASAKI (1970) pointed out that the sulfur isotopic exchange between sulfate and sulfide in submarine hydrothermal system is more likely the cause of the observed isotopic pattern in the "volcanic type" deposits. Our results are consistent with his interpretation.

\section{CONCLUSIONS}

From the foregoing discussion, we conclude:

1) The sulfate ions in barite, gypsum and anhydrite of the black ore deposits probably originated from the sea water sulfates of Miocene age. Connate or actual sea 
water sulfates probably are the ultimate source of sulfate in many submarine hydrothermal systems.

2) However, these sea water sulfates underwent oxygen and probably sulfur isotopic exchange in the hydrothermal processes. The oxygen isotopic compositions of sulfate are largely determined by the isotopic composition of water as well as the temperature. Thus, the sulfate ions in the black ore deposits differ widely in their oxygen isotopic ratios, reflecting the variation in the nature and/or the temperature of waters which operated in various stages of the ore forming and post-depositional processes.

3) On the other hand, because the sulfate ions of oceanic origin were the predominant sulfur species in the ore-forming solutions, the original $\delta^{34} \mathrm{~S}$ values of sulfate ions remain virtually unchanged during mineralization whether or not isotopic exchange took place between sulfate and sulfide.

4) In the cupriferrous iron sulfide ore deposits of the late Paleozoic age, the isotopic pattern of the sulfates is quite similar to that of the Miocene sulfates, except that the late Paleozoic sulfates have $\delta^{34} \mathrm{~S}$ values close to those of the Permian sea water sulfates.

5) Satin spars in the Noto and Wanibuchi mines may have been contaminated by sulfates which were subjected to intense sulfate reduction by bacteria in a limited supply of sea water.

\section{ACKNOWLEDGEMENTS}

We are indebted to Drs. T. TATSUMI of the University of Tokyo, A. SASAKI of the Geological Survey of Japan, S. SUGIURA of Kanazawa University and T. MATSUMOTO of this Institute for their valuable discussion on the subjects, and to Dr. E. CHENEY of the University of Washington for his critically reading the manuscript and correcting the English. One of us (S.O.) thanks Dr. S. OANA of Nagoya University for his interests in the present research. Our thanks are also due to Misses $\mathrm{H}$. TANAKA and S. MASHIMA of this laboratory for their technical assistance.

\section{REFERENCES}

Buschendorf, F., Nielsen, H., Puchelt, H. and RiCKe, W. (1963) Schwefel-Isotopen-Untersuchungen am Pyrit-Sphalerit-Baryt-Lager Meggen/Lenne (Deutschland) und an verschiedenen Devon-Evaporiten. Geochim. Cosmochim. Acta 27, 501-523.

CRAIG, H. (1966) Isotopic composition and origin of the Red Sea and Salton Sea geothermal brines. Science 154, 1544-1548.

Geological Survey of Japan (1960) Geology and Mineral Resources of Japan, 2nd edition.

HARRISON, A. G. and THODE, H. G. (1958) Mechanism of the bacterial reduction of sulfate from isotopic fractionation studies. Trans. Farad. Soc. 54, 84-92.

HARTMANN, M. and NiELSEN, H. (1966) Sulfur isotopes in the hot brines and sediment of Atlantis II Deep (Red Sea). Marine Geol. 4, 305-306.

HASHIMOTO, K., KAMONO, H. and HAYASHI, S. (1962) On the Uchinotai Kuroko (black ore) deposit, Kosaka mine. Kozanchishitsu (Mining Geology), 12, 129-142 (in Japanese). 
HoERING, T. C. and KENNEDY, J. W. (1957) The exchange of oxygen between sulfuric acid and water. J. Amer. Chem. Soc. 79, 56-60.

IWAO, S. (1956) Hydrothermal gypsum deposits of the Wanibuchi mine, Japan, with special reference to alteration of wall rocks. Jap. J. Geol. Geog. 27, 105-130 (in Japanese).

KASENO, Y. (1963) Geology of Southern Noto Peninsula, Central Japan, with reference to the Cenozoic history. Sci. Rep. Kanazawa Univ. 8, 541-568.

LLOYD, R. M. (1968) Oxygen isotopic behavior in the sulfate-water system. J. Geophys. Res. 73, 6099-6110.

LONGINELli, A. and CRAIG, H. (1967) Oxygen-18 variations in sulfate ions in sea water and saline lakes. Science 156, 56-59.

Miller, A. R., Densmore, C. D., Degens, E. T., Hathaway, J. C., Manheim, F. T., MCFARlin, P. F., Pocklington, R. and Jokela, A. (1966) Hot brines and recent iron deposits in deeps of the Red Sea. Geochim. Cosmochim. Acta 30, 341-359.

MizUTANI, Y. and RAFTER, T. A. (1969a) Oxygen isotopic composition of sulphates. Part III. Oxygen isotopic fractionation in the bisulphate-water system. N.Z.J. Sci. 12, 54-59.

MizUTANI, Y. and RAFTER, T. A. (1969b) Oxygen isotopic composition of sulphates. Part IV. Bacterial fractionation of oxygen isotopes in the reduction of sulphate and in the oxidation of sulphur. ibid. 12, 60-68.

NAKAI, N. (1967) The isotopic ratios of sulfur compounds in sulfide ore deposits (abstract). The annual meeting of the Geochemical Society of Japan, held in Nagoya University, 1967 (in Japanese).

NAKAI, N. (1968) Geochemical estimation of temperature and state of $\mathrm{H}_{2} \mathrm{O}$ at the bottom of the geothermal wells. Chinetsu (Geothermal Heat) No.17, 45-52 (in Japanese).

NIELSEN, H. and RICKE, W. (1964) Schwefel-Isotopenverhältnisse von Evaporiten aus Deutschland; ein Beitrag zur Kenntnis von $\delta^{34} \mathrm{~S}$ im Meerwasser-sulfat. Geochim. Cosmochim. Acta 28, 577-591.

NIELSEN, H. (1965) Schwefelisotope im marinen Kreislauf und das $\delta^{34} \mathrm{~S}$ der früheren Meere. Geol. Rundschau 55, 160-172.

OANA, S. and ISHIKAWA, H. (1966) Sulfur isotopic fractionation between sulfur and sulfuric acid in the hydrothermal sulution of sulfur dioxide. Geochem. J. 1, 45-50.

OSHIMA, T. (1958) Geology and ore deposits of the Yanahara mine, with reference to structural control. Kozanchishitsu (Mining Geology), 8, 135-152 (in Japanese).

RAfTer, T. A. (1967) Oxygen isotopic composition of sulphates. Part I. A method for the extraction of oxygen and its quantitative conversion to carbon dioxide for isotope ratio measurements. N.Z.J. Sci. 10, 493-510.

RAFTER, T. A. and MizUTANI, Y. (1967) Oxygen isotopic composition of sulphates. Part II. Preliminary results on oxygen isotopic variation in sulphates and the relationship to their environment and to their $\delta^{34} \mathrm{~S}$ values. ibid. 10, 816-840.

SAKAI, H. (1968) Isotopic properties of sulfur compounds in hydrothermal processes. Geochem. J. 2, 29-49.

SAKAI, H. and YAMAMOTO, M. (1966) Fractionation of sulfur isotopes in the preparation of sulfur dioxide. An improved technique for the precision analysis of stable sulfur isotopes. ibid. 1, 35-42.

Sakazaki, H., OtaGaki, T., Tsukada, Y., Hirayama, H., Osada, T. and SuZuki, H. (1965) Geology and ore deposits of the Shakanai mine in Akita-Pref., Japan. Kozanchishitsu (Mining Geology, 15, 157-168 (in Japanese). 
SANGSTER, D. F. (1968) Relative sulphur isotope abundances of ancient seas and strata-bound sulphide deposits. Geological Association of Canada, Proceedings 19, 79-91.

SASAKI, A. (1970) Sea water sulfate as a possible determinant of sulfur isotopic compositions in some strata-bound sulfide ores. Geochem. J. 4, 41-51.

STEINER, R. L. and RAFTER, T. A. (1966) Sulfur isotopes in pyrite, pyrrhotite, alunite and anhydrite from steam wells in the Taupo volcanic zone, New Zealand. Econ. Geol. 61, $1115-1129$.

SugiURA, S. (1956) Progress in economic geology, edt. Watanabe, Fuzanbo, 519.

TATSUMI, T. (1965) Sulfur isotopic fractionation between co-existing sulfide minerals from some Japanese ore deposits. Econ. Geol. 60, 1645-1659.

THODE, H. G., MONSTER, J. and DUNFORD, H. B. (1961) Sulfur isotope geochemistry. Geochim. Cosmochim. Acta 25, 159-174.

YAMAMOTO, M., OGUSHI, N. and SAKAI, H. (1968) Distribution of sulfur isotopes, selenium and cobalt in the Yanahara ore deposits, Okayama-Pref., Japan. Geochem. J. 2, 137-156.

WATANABE, T. (1957) On the origin of the bedded cupriferrous iron sulfide and manganese ore deposits in Japan. Kozanchishitsu (Mining Geology) 7, 87-97 (in Japanese). 